\title{
Competition Policy and Antitrust Law: Introduction to the Special Issue
}

\author{
Gregory T. Gundlach
}

$\mathbf{T}$ Today, few marketers are unaware of the implications of competition for reaching consumers. Indeed, to win in today's marketplace, marketers must be adept not only in providing value to their customers but also in providing this value in ways that exceed the value offered by their competitors (Kotler and Armstrong 2000). Public policy toward competition and the law of antitrust are intended to ensure that such activities are conducted in ways that enhance competition and increase the welfare of consumers (Hovenkamp 1994).

The special issue brings together a collection of articles that addresses various aspects of competition policy and antitrust law. Included in the special issue are contributions that examine the regulatory origins of antitrust law, its foundations in competition theory, marketing-based research helpful to informing its development, explanations of current enforcement agency activities, insights as to the application of antitrust law to emerging forms of commerce, comparative perspectives on the international application of competition policy, and the special challenges of antitrust law in certain industries. Together, the collection of articles contributes to the further understanding of this important area of public policy.

\section{Overview}

\section{Regulatory Origins}

As public policy, antitrust law rests on a legal framework of statutes, regulations, court decisions, and enforcement agency policies. The Sherman Act of 1890 is the oldest and perhaps most important federal statute. The act has been described as a "comprehensive charter of economic liberty aimed at preserving free and unfettered competition" (Northern Pacific Railway v. U.S 1958). Its actual language, however, is only generally stated. As a consequence, depending on the perspective taken, the act's historical intentions have been interpreted in various ways and have been the matter of public and political debate.

Focusing on this debate, Peter R. Dickson and Philippa K. Wells in their article, "The Dubious Origins of the Sherman Antitrust Act: The Mouse That Roared," examine the act's legislative history as reported in the Congressional Record and captured through commentary appearing in newspapers of the time. Applying the tools of historical analysis, the authors assess the intentions of those involved in the act's development and passage. Their findings provide an infor-

Gregory T. Gundlach is John W. Berry Sr. Professor of Business, Department of Marketing, Mendoza College of Business, University of Notre Dame. mative look at the political economy of the time that yields further understanding of this important antitrust statute.

\section{Competition Theory}

As a public policy goal, antitrust law endeavors to promote consumer welfare through encouraging competitive conduct and protecting the process of competition. Although most antitrust scholars and policymakers presently endorse an economic view of consumer welfare, the nature of economic theory informing this interpretation is now under critical debate. This discourse focuses on the nature of economic thought best suited to inform antitrust analysis.

Contributing to this dialogue, Shelby D. Hunt and Dennis B. Arnett in their article, "Competition as an Evolutionary Process and Antitrust Policy," challenge conventional antitrust analysis that relies on static equilibrium economics. In advocating what amounts to a paradigm shift for how competition policy and antitrust law should be developed, the authors contend that competition is a process and cannot be adequately represented as a series of moving equilibria.

Relying on evolutionary and Austrian economics, the authors present a process theory of competition, known as resource-advantage theory, under development in economics, management, and marketing. The authors discuss its development and implications for competition policy and antitrust. Their thoughtful insights help further the understanding of the cornerstone of antitrust-competition.

\section{Marketing-Based Research}

Although today economics dominates antitrust analysis, various scholars have long suggested that additional modes of understanding are required to adequately address the complexities of competition and inform antitrust law. As economist Oliver Williamson $(1979$, p. 991) observed more than 20 years ago, "Antitrust is an interdisciplinary field that is best served by acknowledging that a deeper understanding of the issues will result by addressing the subject from several points of view."

In addition to economics, various disciplines including marketing study competition and competitive behavior in ways that have relevance to competition policy and antitrust. In their article, "Only the Illusion of Possible Collusion? Cheap Talk and Similar Goals: Some Experimental Evidence," authors Marian Chapman Moore, Ruskin M. Morgan, and Michael J. Moore provide an excellent example of such research. They report on a study that investigates the nature of "cheap talk," or statements by competitors that convey their strategic intentions, and examines whether such statements provide the basis for transmitting information in ways that can facilitate anticompetitive collusion.

Using an experimental design, the authors examine the process by which cheap talk can serve as a competitive sig- 
nal and lead to coordinating versus competitive outcomes. Their work offers an interesting example of research in the field of marketing that focuses on managerial thinking and strategy for understanding competition.

\section{Enforcement Institutions}

Two federal governmental agencies are primarily responsible for enforcing federal antitrust law: the Federal Trade Commission (FTC) and the Antitrust Division of the Department of Justice. Given their enforcement role, understanding the approach taken by these agencies in analyzing competitive behavior is important for understanding federal antitrust law.

To this end, in his article "Supermarket Merger Enforcement," David A. Balto of the FTC examines the key principles of analysis relied on by the agency for recent merger enforcement actions in the supermarket industry. Although the level of merger activity in recent years has been unprecedented across many industries, significant consolidation and competitive restructuring has occurred in the supermarket industry. Through explaining the principles that inform current merger enforcement actions by the FTC, the article provides a road map for the analysis of future mergers and acquisitions in both the supermarket industry and other relevant retail segments.

\section{Emerging Applications}

Competition policy as embodied in the law of antitrust has been built against the economic and marketing realities of what in comparative terms is now often characterized as the "old economy." On the cusp of a "new economy," what challenges lie ahead in applying antitrust concepts and analysis in an economy shifting more and more toward electronic commerce?

Addressing this question, Albert A. Foer, president of the American Antitrust Institute, examines the general framework of antitrust and its application to electronic commerce. Focusing on familiar antitrust concepts and tracing the activities of the FTC, the author explores key challenges and prospective solutions for applying antitrust law in this new economy. His findings provide thoughtful commentary on the key challenges facing antitrust into the future.

\section{International Perspectives}

Federal antitrust law applies to international transactions by foreign companies that have an effect in the United States. In addition, an extensive body of competition policy and law may be found outside the United States. Developed by individual countries, through member nation agreements (e.g., European Union Area Agreement), or as international agreements ratifying such agreements, these laws provide an international web of public policy toward competition.

Because of their distinct origins, these policies and laws do not always rest on the same traditions or reflect the same philosophies toward competition as those found in the United States. These differences provide the focus for authors Christophe Collard, Michael Pustay, Christophe
Roquilly, and Asghar Zardkoohi in their article, "Competitive Cross-Couponing: A Comparison of French and U.S. Perspectives."

Examining competitive cross-couponing, or the strategy of a firm issuing a coupon that discounts the price of its products when a consumer purchases a rival firm's product, the authors explore the legal approaches for evaluating such practices in the United States and France. Their article provides comparative insights into the two approaches and reveals their key distinctions.

\section{Special Applications}

Finally, although the federal antitrust laws apply generally to interstate commerce, some industries and classes of organizations have been granted specific statutory immunity or have otherwise been exempted from the law. In some cases, these exemptions reflect the unique aspects of the commercial activity to which they apply. One such area is professional sports. Although for the most part held to the antitrust laws, narrow areas in professional sports have received limited immunity. As a result, understanding and applying the antitrust laws to professional sports is particularly complex.

Addressing this complexity, Debbie Thorne, Linda Berns Wright, and Scott Ashley Jones in their article, "The Impact of Sports Marketing Relationships on Antitrust Issues in the United States," propose that the exchange relationship or dyad as a unit of analysis provides a helpful basis for organizing the various interests that transcend antitrust questions in professional sports. Focusing on dyadic relationships that underlie the sports marketing process, the authors organize and discuss various antitrust issues in professional sports. Their organizational framework helps further the understanding of this complicated area of antitrust.

As editor of the special issue, I am grateful to the many authors who elected to share their scholarly work with the journal. Without their contributions, special issues of this type would not be possible. I am also indebted to the reviewers, who provided thoughtful commentary and guidance to the authors and myself. Finally, it is my hope that the contributions to this special issue are found to be of interest to the field and that they stimulate further work on this important area of public policy in the years to come.

\section{References}

Hovenkamp, Herbert (1994), Federal Antitrust Policy: The Law of Competition and lts Practice. St Paul, MN: West Publishing.

Kotler, Philip and Gary Armstrong (2000), Principles of Marketing, 9th ed. Upper Saddle River, NJ: Prentice Hall.

Northern Pacific Railway v. United States (1958), 356 U.S. 1.

Sherman Act (1890), 26 Stat. 209, as amended, 15 U.S.C.A. Sections 1-7 (1980).

Williamson, Oliver (1979), “Assessing Vertical Market Restrictions: Antitrust Ramifications of the Transaction Cost Approach," University of Pennsylvania Law Review, 127 (April), 953-93. 
Copyright of Journal of Public Policy \& Marketing is the property of American Marketing Association. The copyright in an individual article may be maintained by the author in certain cases. Content may not be copied or emailed to multiple sites or posted to a listserv without the copyright holder's express written permission. However, users may print, download, or email articles for individual use. 